\title{
Supporting S1_Figure
}

A

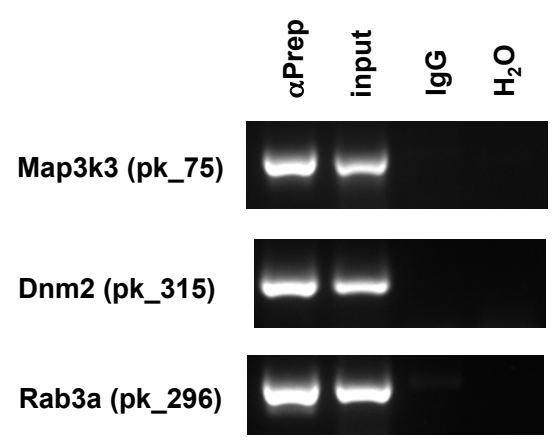

B

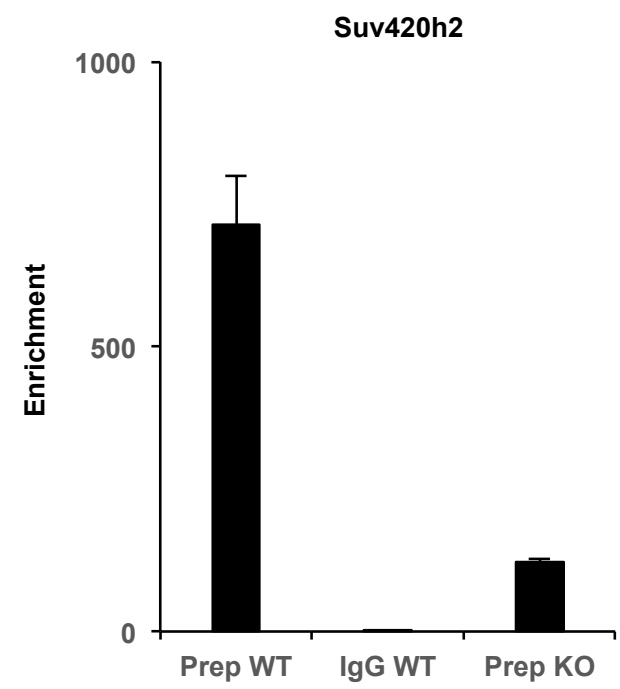

